\title{
Purification from Bovine Serum of a Survival-Promoting Factor for Cultured Central Neurons and Its Identification as Selenoprotein-P
}

\author{
Jun Yan and John N. Barrett \\ Department of Physiology and Biophysics, University of Miami School of Medicine, Miami, Florida 33101
}

\begin{abstract}
We purified from bovine serum a glycoprotein that promotes the survival of rat embryonic neurons cultured from septum and other brain regions. A 40,000-fold purification was achieved by using a combination of ammonium sulfate precipitation, $\mathrm{Zn}^{2+}$ affinity chromatography, Cibacron blue 3-GA dye affinity chromatography, $A B x$ ion exchange chromatography, and preparative PAGE. The active protein had an apparent molecular weight of $50-60 \mathrm{kDa}$. The concentration required for half-maximal survival $\left(E_{50}\right)$ was $12 \mathrm{ng} / \mathrm{ml}(\sim 200 \mathrm{pm})$ for the final fraction. Amino acid sequencing after cyanogen bromide cleavage yielded two sequences that are homologous to regions of
\end{abstract}

Most mammalian cells, including neurons, require the presence of serum for long-term survival and/or differentiation in culture. Withdrawing serum from neuronal cultures usually results in cell death (Howard et al., 1993; Takeshima et al., 1994; Ferrari et al., 1995; Miller and Johnson, 1996). However, the use of serum has many disadvantages, such as toxicity at high concentrations (García et al., 1992) and the variability of different lots. This variability, plus the complex composition of serum, makes medium containing serum a potential source of complications in studies of the effects of neurotrophic factors. The mitogenic effect of the serum on non-neuronal cells also makes it hard to maintain neuron-rich cultures. Efforts to make better, serum-free, chemically defined media for neuronal cell culture have included the addition of known survival-promoting reagents to existing synthetic media. For example, the widely used N2 medium adds insulin, transferrin, progesterone, putrescine, and selenium to a 1:1 mixture of DMEM and Ham's F-12 medium [Bottenstein and Sato (1979); see also Aizenman and de Vellis (1987)]. However, even with these modified defined media, the pretreatment of substrata with serum, the preincubation of cells in serum-containing media, and/or cell densities $>1000 / \mathrm{mm}^{2}$ frequently are needed to achieve good neuronal survival (Skaper et al., 1979; Messer et al.,

\footnotetext{
Received June 17, 1998; revised Aug. 7, 1998; accepted Aug. 17, 1998.

This work was supported by funds from National Institutes of Health (NS 12207), the National Parkinson Foundation, and Cytotherapeutics, Incorporated (Providence, RI). Dr. Yan's studies were supported by the University of Miami, and this work was submitted in partial fulfillment of his Ph.D. requirements. We thank Bao-ping Pang, Qinjie Oyang, Doris Nonner, and the staffs of the University of Miami and University of Florida protein sequencing facilities for technical assistance; Drs. Leonard Gralnik and Barry Brass for contributions to the purification protocol; Drs. Keith Brew, Nirupa Chaudhari, Gerhard Dahl, and Scott Whittemore for valuable discussions; and Ms. Sara Villamil and Dr. Ellen Barrett for help with this manuscript.

Correspondence should be addressed to Dr. John Barrett, Department of Physiology and Biophysics, R-430, University of Miami School of Medicine, P.O. Box 016430, Miami, FL 33101.

Dr. Yan's present address: National Institutes of Health, 36 Convent Drive, Mail Stop Center 4092, Building 36, Room 3D02, Bethesda, MD 20892.

Copyright (C) 1998 Society for Neuroscience $0270-6474 / 98 / 188682-10 \$ 05.00 / 0$
}

deduced sequence of the selenoprotein-P (SPP) family in bovine, rat, and human. Antibodies against a synthetic peptide within the bovine SPP sequence immunoprecipitated and inhibited the survival-promoting activity of a partially purified serum fraction. The purified protein supported neuronal survival more effectively than inorganic selenium. These results suggest that SPP or an SPP-like protein contributes to the neuronal survival-promoting activity of serum.

Key words: central neurons; neuronal survival; selenium; selenoprotein-P; serum; neurotrophic factor

1980; Yavin and Yavin, 1980). Thus it is important to identify the specific serum components that promote neuronal survival.

Kaufman and Barrett (1983) demonstrated that the survivalpromoting activity of horse serum for neurons from several regions of the rat CNS was enriched in a $45-80 \mathrm{kDa}$ gel filtration fraction. This fraction did not promote the proliferation of nonneuronal cells. We report here the purification from bovine serum of a selenoprotein-P (SPP)-like protein and present evidence that this molecule is responsible for part of the neuronal survivalpromoting activity of serum. SPP is a selenium (Se)-rich compound, and rat and human SPPs have been purified and sequenced (Burk and Hill, 1994). Two cDNA sequences from bovine cerebellum encoding SPP or SPP-like proteins have been identified (Saijoh et al., 1995), but neither bovine protein has been purified previously.

Portions of this work have appeared in abstract form (Yan and Barrett, 1996).

\section{MATERIALS AND METHODS}

\section{Cell culture}

Septal tissue was dissected from 15 d gestation (E15) Sprague Dawley rats (Charles River Laboratories, Wilmington, MA); at this embryonic age most septal cells are neurons. Tissue was maintained in a cryopreservation medium (Kawamoto and Barrett, 1986) at $4^{\circ} \mathrm{C}$ for $4 \mathrm{~d}$ and then mechanically dissociated by trituration at room temperature in a defined culture medium (N5) (Kawamoto and Barrett, 1986) supplemented with $1 \mathrm{mg} / \mathrm{ml}$ bovine serum albumin (BSA; free of fatty acids and globulins, Sigma A-0281), $20 \mu \mathrm{g} / \mathrm{ml}$ bovine transferrin, $5 \mu \mathrm{g} / \mathrm{ml}$ bovine insulin, 10 $\mu \mathrm{M} 2$-mercaptoethanol (a sulfhydryl reducing agent), $50 \mu \mathrm{g} / \mathrm{ml}$ gentamicin sulfate, and $1 \mathrm{~mm}$ HEPES. Preliminary work showed that insulin (probably acting via receptors for insulin-like growth factor I) (Rechler and Nissley, 1986; Aizenman and de Vellis, 1987) and transferrin enhanced the neuronal survival that was measured in the presence of active serum fractions. The survival-promoting effects of the serum fraction were not duplicated by known neurotrophic molecules, including basic fibroblast growth factor, ciliary neurotrophic factor, or neurotrophins (each at $100 \mathrm{ng} / \mathrm{ml}$ ) (Nonner et al., 1996; Yan, 1996). Cells were plated at a density of $3 \times 10^{5} / \mathrm{ml}$ into poly-L-lysine-coated Terasaki microwell plates (Robbins Scientific, Sunnyvale, CA) at $10 \mu \mathrm{l} /$ well. The cell density at the bottom of the well was 450 cells $/ \mathrm{mm}^{2}$. Cultures were incubated at 
$35^{\circ} \mathrm{C}$ in $5 \% \mathrm{CO}_{2} / 95 \%$ humidified air. Approximately $88 \%$ of attached neurons survived the first $24 \mathrm{hr}$ in culture.

\section{Bioassay}

Fractions derived from the purification procedures described below were equilibrated with Bis-Tris-buffered saline (10 mm Bis-Tris- $\mathrm{HCl}$ and 150 $\mathrm{mm} \mathrm{NaCl}, \mathrm{pH}$ 7.4), using Centricon 10 ultrafilters (Amicon, Beverly, MA). Test fractions were added to the cultures on the third day in vitro (3 DIV) by using at least four different dilutions (fivefold concentration increments). Sample volumes were $\leq 5 \%$ of the total medium in the well. Negative control cultures were treated with extra BSA at concentrations greater than or equal to the protein concentration of the test sample. Positive control cultures were treated with the active EDTA-citrate eluate from the first $\mathrm{Zn}^{2+}$ affinity column (see below) at concentrations high enough to support maximal neuronal survival. Viable neurons were counted between 5 and 7 DIV, when most cells in the negative control wells were dead. A viable neuron was defined as a cell with a phase-dark cell body surrounded by a phase-bright ring, with fine processes at least three times as long as the diameter of the soma. Relative neuronal survival was calculated as the number of neurons supported by a specific sample normalized to the number surviving in positive control wells. The total activity of a sample was defined in biological units (BU), calculated by dividing the total protein concentration by the $\mathrm{EC}_{50}$, the protein concentration that supported half-maximal neuronal survival. The specific activity was expressed as $\mathrm{BU} / \mathrm{mg}$ protein, the reciprocal of the $\mathrm{EC}_{50}$.

For most samples the protein concentration was measured by using the Bradford reagent (Bio-Rad, Melville, NY). Protein concentrations $<100$ $\mu \mathrm{g} / \mathrm{ml}$ were determined with the NanoOrange protein quantitation kit (Molecular Probes, Eugene, OR).

\section{Purification of neuronal survival-promoting activity from serum}

Major steps in the purification protocol are outlined below; see Yan (1996) for further details.

Ammonium sulfate precipitation and metal chelation. One liter of bovine serum (JRH Biosciences, Lenexa, KS) was precipitated with $35 \%$ ammonium sulfate in the presence of phenylmethanesulfonyl fluoride (150 $\mu \mathrm{M})$, a protease inhibitor. The supernatant was precipitated with $65 \%$ ammonium sulfate. This precipitate was dissolved in 11 of buffer $(10 \mathrm{~mm}$ imidazole and $200 \mathrm{~mm} \mathrm{NaCl}, \mathrm{pH} 7.0$ ) and passed through a $30 \mathrm{ml}$ Chelex-100 (Bio-Rad) column.

$\mathrm{Zn}^{2+}$ and Cibacron blue dye affinity chromatography. A chelating Sepharose Fast Flow column $(45 \times 62 \mathrm{~mm}$; Pharmacia Biotech, Piscataway, NJ) was charged with $\mathrm{Zn}^{2+}$ and loaded with the flow-through sample from the Chelex-100 column. Proteins adsorbed on the $\mathrm{Zn}^{2+}$ affinity column were eluted sequentially with 30 and $80 \mathrm{~mm}$ imidazole, $\mathrm{pH}$ 7.0, followed by $25 \mathrm{~mm}$ EDTA plus $80 \mathrm{~mm}$ Na-citrate. The EDTAcitrate eluate was loaded onto Cibacron blue 3-GA dye affinity columns (Econo-Pac blue cartridges, Bio-Rad), which were washed with $0.5 \mathrm{M}$ $\mathrm{NaCl}$ in $10 \mathrm{~mm}$ Bis-Tris buffer, $\mathrm{pH}$ 7.4, and eluted with $3 \mathrm{~m} \mathrm{NaCl}$. This procedure removed EDTA and citrate and slightly increased the specific activity (see Table 1). The $3 \mathrm{M} \mathrm{NaCl}$ eluate was loaded directly onto two $5 \mathrm{ml}(16 \times 25 \mathrm{~mm})$ Pharmacia Biotech HiTrap chelating affinity columns charged with $\mathrm{Zn}^{2+}$. These columns removed impurities that had been retained on the first large $\mathrm{Zn}^{2+}$ affinity column and were eluted in the same manner. After the second $\mathrm{Zn}^{2+}$ affinity column the fractions were stored under argon, and chromatography buffers were equilibrated with argon to minimize protein oxidation.

Mixed mode ABx ion exchange chromatography. The EDTA-citrate eluate from the second $\mathrm{Zn}^{2+}$ affinity column was loaded in $20 \mathrm{~mm}$ 3 -[ $N$-morpholino]propanesulfonic acid (MOPS) and $50 \mathrm{~mm} \mathrm{NaCl}, \mathrm{pH}$ 7.3, onto a column packed with BackerBond-ABx zwitterionic resin (40 $\mu \mathrm{m}$ bead size; Baker, Phillipsburg, NJ). Elution was done with a shallow $\mathrm{NaCl}$ gradient (50 mM to $1 \mathrm{M}$ in MOPS buffer). ABx proved to be the best of multiple tested resins for separating the survival-promoting activity from a contaminating protein, identified by $\mathrm{N}$-terminal sequencing to be histidine-rich glycoprotein $(\sim 80 \mathrm{kDa})$ (Koide et al., 1986).

Sodium dodecylsulfate-polyacrylamide gel electrophoresis (SDS-PAGE). All SDS-PAGE was performed at neutral pH (Yan and Barrett, 1994), because in low ionic strength conditions the survival-promoting activity precipitated at $\mathrm{pH} 5-6$ (consistent with its estimated isoelectric point of 5.5-5.8) (Kaufman and Barrett, 1983). The 7\% resolving gel and 4\% stacking gel mixtures were made by mixing appropriate amounts of acrylamide stock solution (29.2\% acrylamide and $0.8 \%$ bisacrylamide) with fourfold concentrated gel buffer $(1 \mathrm{M}$ Tris- $\mathrm{HCl}$ and $0.2 \%$ SDS, $\mathrm{pH}$
7.1) and water. Polymerization was achieved by adding ammonium persulfate and tetramethylethylenediamine to $0.05 \%$ for the resolving gel and to $0.2 \%$ for the stacking gel.

Gels were preelectrophoresed in the gel buffer containing $0.1 \mathrm{~mm}$ thioglycolate for $30 \mathrm{~min}$ to remove gel polymerization by-products. Samples were diluted 1:1 with twofold Laemmli SDS sample buffer (120 mM Tris-HCl, $4 \%$ SDS, $20 \%$ glycerol, and $0.025 \%$ bromophenol blue, with/without $120 \mathrm{~mm}$ dithiothreitol for reducing/nonreducing gels) and boiled for $5 \mathrm{~min}$. Electrophoresis was performed in the running buffer [ 30 $\mathrm{mm}$ Tris, $68 \mathrm{~mm} N$-Tris, and [hydroxymethyl] methyl-3-aminopropanesulfonic acid (TES), $0.1 \%$ SDS, $\mathrm{pH} 7.2]$ plus $0.1 \mathrm{~mm}$ thioglycolate at a constant current $(30 \mathrm{~mA})$ for $2.5 \mathrm{hr}$.

Analytical gels, used to assess the progress of the purification, were fixed and stained with either Fast Stain (Coomassie blue G-250; Zoion Research, Allston, MA) or silver stain (Bio-Rad). Preparative gels were used for the final purification step; proteins were eluted into Centricon 10 ultrafilters, concentrated, renatured in Bis-Tris-buffered saline, $\mathrm{pH}$ 7.0, and washed extensively to remove residual SDS.

Electrotransfer and amino acid sequencing. After SDS-PAGE the proteins were transferred electrophoretically onto Immobilon $\mathrm{P}^{\mathrm{SQ}}$ membranes (for sequencing, Millipore, Bedford, MA; Moos et al., 1988) or nitrocellulose membranes (for Western blots, Bio-Rad) at $150 \mathrm{~mA}$ for 1.5 hr. The electrotransfer solution contained $40 \mathrm{~mm}$ Tris, $40 \mathrm{~mm}$ TES, $0.03 \%$ SDS, and $10 \%$ methanol, $\mathrm{pH} 8.3$.

Ponceau S-stained bands on Immobilon $\mathrm{P}^{\mathrm{SQ}}$ membrane were excised for direct $\mathrm{N}$-terminal sequencing or were cleaved by incubation with cyanogen bromide (1:20) in $70 \%$ formic acid for $18 \mathrm{hr}$ at room temperature in the dark. Samples washed with distilled water were air-dried and sequenced with automated Edman degradation on an Applied Biosystems Precise Sequencer (Foster City, CA).

\section{Antibody production, immunoprecipitation, and Western blots}

A peptide was synthesized to match a 15 -amino-acid segment shared by the deduced sequences of bovine SPP and SPP-like proteins: (244) His-His-Arg-His-Lys-Gly-Pro-Gln-Arg-Gln-Gly-His-Ser-Asp-Asn (259). This sequence is close to the putative $\mathrm{C}$-terminal and has high scores for hydrophilicity and surface probability (Kyte and Doolittle's method, using DNASIS from Hitachi Software). A cysteine was added to the $\mathrm{N}$ terminal of the peptide for sulfhydryl coupling of the peptide to a carrier protein (hemocyanin). The immunogen (peptide linked to carrier) was injected into rabbits (Genemed Biotechnologies, South San Francisco, CA).

Antibodies were affinity-purified with the peptide immobilized on agarose resin by the SulfoLink kit from Pierce (Rockford, IL), washed with PBS, pH 7.4, and eluted with $20 \mathrm{~mm}$ Na-citrate, $\mathrm{pH}$ 2.8. Antibodies were neutralized and concentrated to $\sim 1 \mathrm{mg} / \mathrm{ml}$ with Centricon 30 concentrators.

For immunoprecipitation studies, affinity-purified antibodies $(0.6 \mathrm{mg} /$ $\mathrm{ml}$ ) were added to the active $\mathrm{ABx}$ fraction $(0.06 \mathrm{mg} / \mathrm{ml}$ protein) and incubated for $1 \mathrm{hr}$. This mixture was incubated with protein A beads (Pharmacia Biotech) for $4 \mathrm{hr}$ to precipitate antigen-antibody complexes ( $4^{\circ} \mathrm{C}$ with gentle rotation). The supernatant was diluted 20 -fold in culture medium and bioassayed.

For Western blots, nitrocellulose membranes blotted with protein samples were incubated with $10 \mathrm{mg} / \mathrm{ml} \mathrm{BSA}$ in PBS overnight at $4^{\circ} \mathrm{C}$ to block nonspecific binding sites and then were probed with affinitypurified primary antibodies $(1 \mu \mathrm{g} / \mathrm{ml})$ overnight at $4^{\circ} \mathrm{C}$. Antibodies were diluted in $50 \mathrm{~mm}$ Tris- $\mathrm{HCl}, 150 \mathrm{~mm} \mathrm{NaCl}, 1 \mathrm{mg} / \mathrm{ml} \mathrm{BSA}$, and $0.5 \%$ Tween 20, $\mathrm{pH}$ 7.6. The remaining steps were performed at room temperature with gentle shaking, using biotinylated anti-rabbit IgG as the secondary antibody and avidin-linked alkaline phosphatase (Vectastain ABC-AP kit, Vector Laboratories, Burlingame, CA).

\section{Reagents}

Unless otherwise noted, all reagents for cell culture and chromatography were purchased from Sigma (St. Louis, MO). TES was obtained from Calbiochem (La Jolla, CA); other reagents for electrophoresis were purchased from Bio-Rad. Antibodies against neuron-specific class III $\beta$-tubulin (TUJ1) (Lee et al., 1990) and the $160 \mathrm{kDa}$ neurofilament protein (NN18) were obtained from BABCO (Richmond, CA) and Sigma, respectively; these antibodies were detected with the Vectastain ABC-AP kit. 

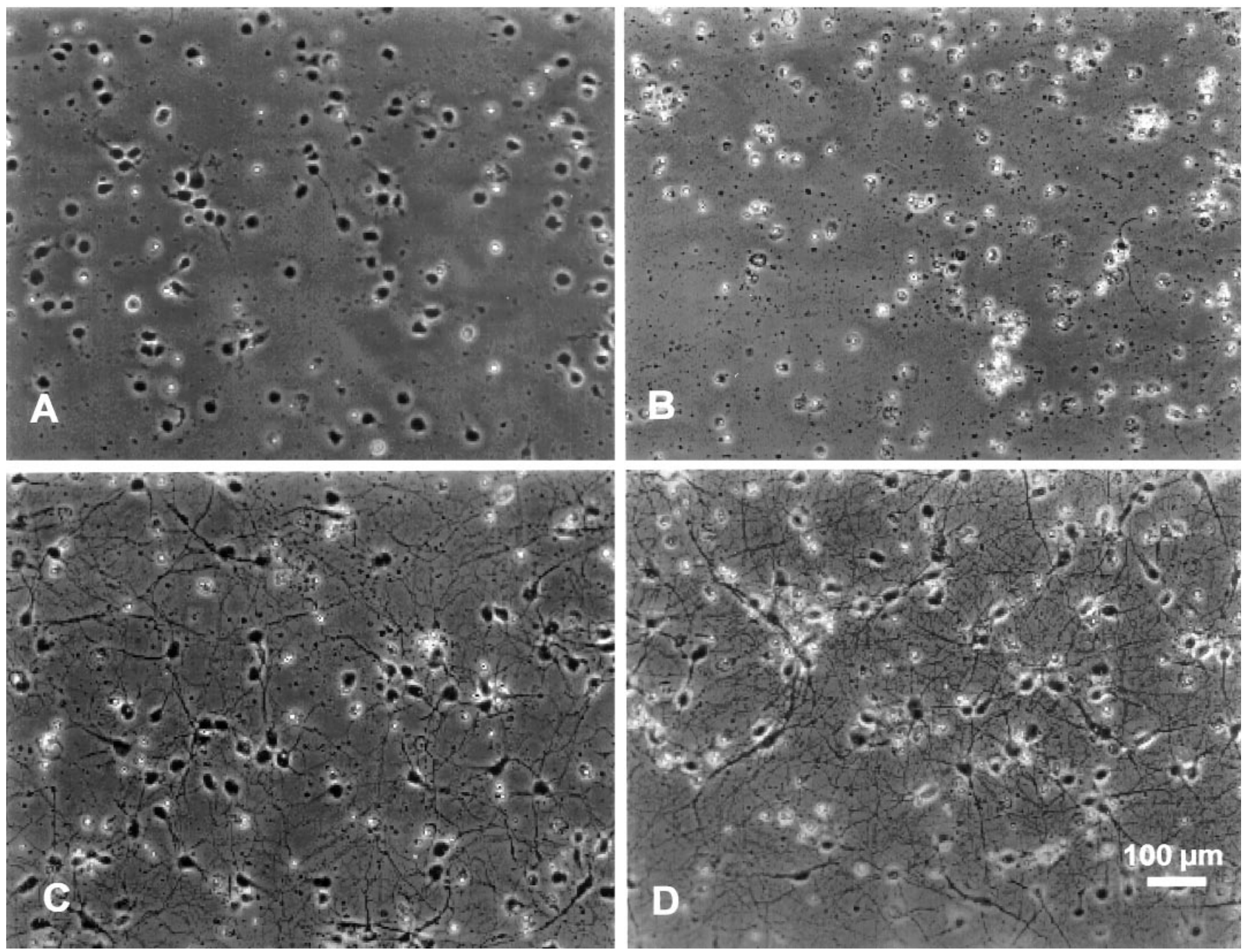

Figure 1. Septal neurons dissected at E15 and grown in the presence or absence of survival-promoting serum fraction. $A$, At $1 \mathrm{DIV}$ in defined medium (see Materials and Methods). B, At 8 DIV in defined medium with extra BSA. Most neurons are dead and few have processes. $C, D$, At 8 and 13 DIV, respectively, in active ABx serum fraction $(12 \mathrm{ng} / \mathrm{ml})$. Many neurons survive and have long, branched processes. Serum fraction or BSA was added at 3 DIV. Scale bar, $100 \mu \mathrm{m}$.

\section{Statistical analysis}

Statistical analysis consisted of one-way ANOVA, followed by Dunnett's multiple comparisons test to compare means and SD from various test samples with those of BSA controls (GraphPad InStat, Intuitive Software for Science, San Diego, CA).

\section{RESULTS}

\section{Serum fraction supports neuronal survival}

After the first day in vitro (1 DIV) the cells had diameters of 13-20 $\mu \mathrm{m}$, and some already had short processes (Fig. 1A). Cell numbers remained fairly constant until $3 \mathrm{DIV}$, when test samples were added. By 5-8 DIV almost all neurons in the BSA control wells were dead (Fig. 1B). In the presence of active serum fractions $50-80 \%$ of the cells present at 1 DIV survived, and many had the rounded cell body and long, branched processes used to identify neurons (Fig. $1 C$ ). In week-old cultures grown in this serum fraction, $65 \pm 12 \%$ (SEM, $n=10$ wells) of the cells were immunoreactive for a neuron-specific isotype of $\beta$-tubulin, and $65 \pm 14 \%(n=17)$ were immunoreactive for the $160 \mathrm{kDa}$ neurofilament protein (data not shown). Some purified active fractions that were added only once at 3 DIV supported neuronal survival for several weeks (e.g., Fig. 1D).

\section{Purification of neuronal survival factor from serum}

The purification scheme described in Materials and Methods was established after many different chromatographic and electrophoretic procedures were tested. Table 1 summarizes the $\mathrm{EC}_{50}$ values and specific and total activities obtained at each stage of the purification. The initial ammonium sulfate precipitation, followed by $\mathrm{Zn}^{2+}$ affinity chromatography, helped to separate the survival-promoting activity from albumin, an abundant serum protein with a molecular weight similar to that of the survivalpromoting activity. These two steps yielded a greater initial purification, had a larger capacity, and produced less damage to the active protein(s) than the acid gel filtration method that was used in a previous partial purification (Kaufman and Barrett, 1983).

Survival-promoting activity bound strongly to the $\mathrm{Zn}^{2+}$ affinity column; material with the highest specific activity was not eluted by up to $80 \mathrm{~mm}$ imidazole. Relatively few proteins exhibit 


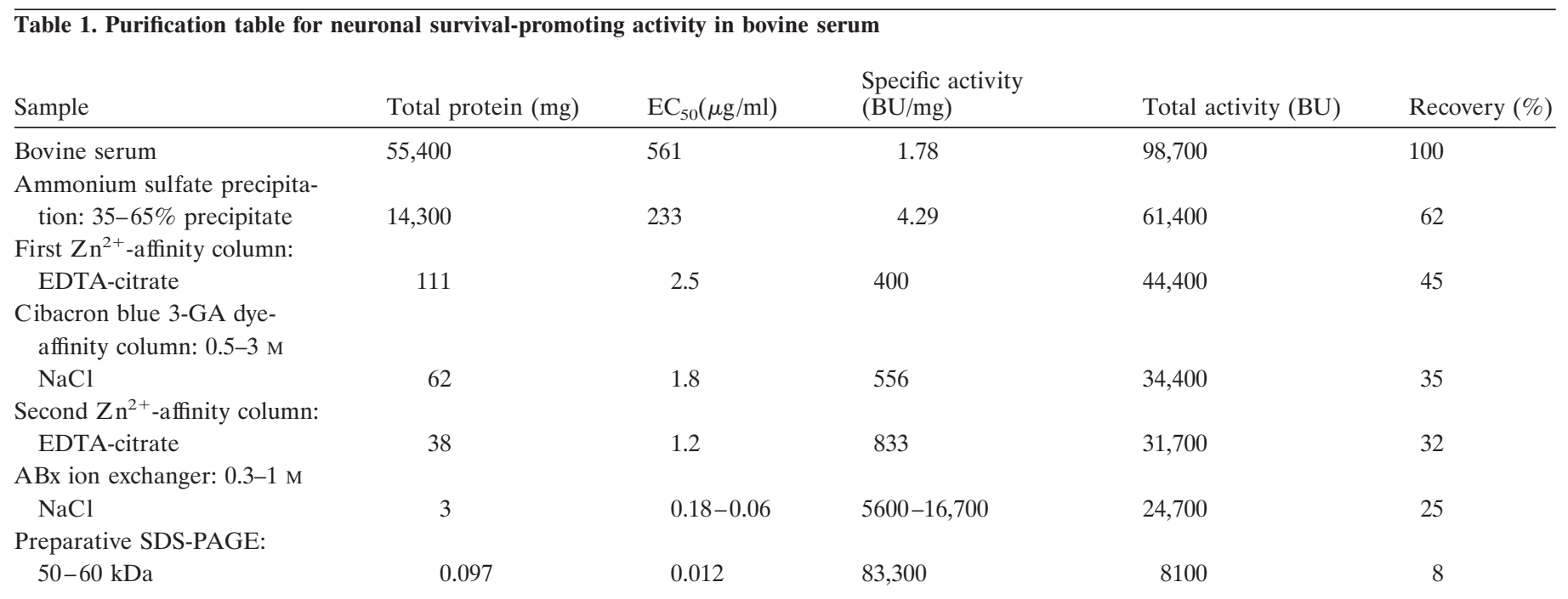

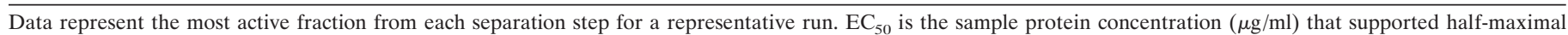

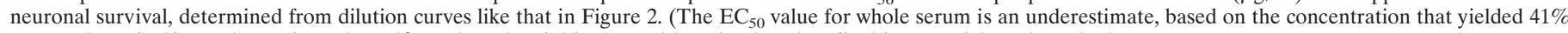
neuronal survival.) Total protein and specific and total activities were determined as described in Materials and Methods.

such strong $\mathrm{Zn}^{2+}$ binding, consistent with the finding that the first $\mathrm{Zn}^{2+}$ affinity column produced an almost 100 -fold increase in specific activity. This strong binding suggests that some of the survival-promoting components of serum have a high histidine (and/or cysteine) content (Yip et al., 1989).

Figure 2 illustrates an SDS-PAGE analysis used to estimate the molecular weight (MW) of the major survival-promoting activity in the active EDTA-citrate eluate from the first $\mathrm{Zn}^{2+}$ affinity column. The active eluate was divided and loaded onto two preparative SDS-PAGE gels, one run under nonreducing and the other under reducing conditions. The top panels in Figure 2 plot the total activity and total protein determined for 10 samples that were cut and electroeluted from the nonreducing (Fig. 2A) and reducing (Fig. $2 B$ ) preparative gels. The bottom panels show analytical SDS-PAGE run on aliquots from each band, again under nonreducing and reducing conditions. Fractions with the highest total activity (e.g., fraction 6) contained proteins that migrated roughly between ovalbumin and BSA MW markers (45 and $66 \mathrm{kDa}$ ) under both nonreducing and reducing conditions, suggesting that the active molecule is a monomer.

We were surprised that the $\mathrm{ABx}$ column, which binds immunoglobulins, also bound the survival-promoting activity. Figure 3, top, illustrates results from preparative SDS-PAGE of an active sample eluted from the ABx column. Lane $\mathrm{A}$ is a Coomassie blue-stained gel strip cut vertically from one side of the SDSPAGE to show the protein distribution in the entire gel. This stained strip was used as a guide to cut the gel into the illustrated four fractions, which were electroeluted and bioassayed. The $\mathrm{EC}_{50}$ of these fractions is given in the bottom part of Figure 3. As expected, fraction 1 (within the $45-66 \mathrm{kDa} \mathrm{MW}$ range) had the lowest $\mathrm{EC}_{50}, 12 \mathrm{ng} / \mathrm{ml}$. [The adjacent fraction 2, for which the major protein is probably histidine-rich glycoprotein (see Materials and Methods), had an 18-fold lower specific activity.] When fraction 1 was rerun on an analytical gel under nonreducing conditions, it showed predominantly a single diffuse band within the 45-66 kDa range (lane $B$ ). The weak staining at higher MWs was probably attributable to dimerization, because under reducing conditions there was only a single band within the $45-66 \mathrm{kDa}$ range (lane $C$ ). As frequently is observed for monomeric proteins, this band ran at an apparent MW slightly greater than that observed under nonreducing conditions. Perhaps the presence of intramolecular disulfide bonds under nonreducing conditions keeps the active protein(s) more compact so that it migrates slightly faster than under reducing conditions.

The representative purification run that is outlined in Table 1 produced a 46,800-fold increase in specific activity with an $8 \%$ recovery of total activity. Figure 4 plots the survival curves produced by serial dilutions of whole serum and the active fractions obtained after different purification steps, illustrating the progressive decrease in the $\mathrm{EC}_{50}$ as purification proceeded. The lower maximal survival in whole serum is probably attributable to as-yet-unidentified neurotoxic macromolecules, whose effects are independent of the complement cascade (García et al., 1992; Manelli et al., 1997).

\section{Peptides from purified survival factor match sequences in selenoprotein-P}

Protein in fraction 1 was transferred electrophoretically onto Immobilon $\mathrm{P}^{\mathrm{SQ}}$ membrane and subjected to amino acid sequence analysis. Direct sequencing gave no signal despite adequate amounts of protein, suggesting an N-terminal block to Edman degradation sequencing. After the sample was cleaved with cyanogen bromide, two sequences were determined, both of which matched parts of the deduced sequence for bovine SPP (Table 2). The match between the fraction 1 sequences and SPP from rat and human plasma was also very good; all three differences occurred at positions that show interspecies variability. In the deduced bovine SPP sequences, methionine leads the first partial sequence, correlating with the expected cleavage at the $\mathrm{C}$-terminal side of methionine by cyanogen bromide. Tryptophan leads the second partial sequence, possibly correlating with cleavage at tryptophan caused by the extremely acidic $\mathrm{pH}$ used during cyanogen bromide treatment ( $70 \%$ formic acid). The failure to recognize the two cysteines (C) and one selenocysteine (U) is expected for Edman sequencing in the absence of previous reduction and alkylation of the sample. 
A

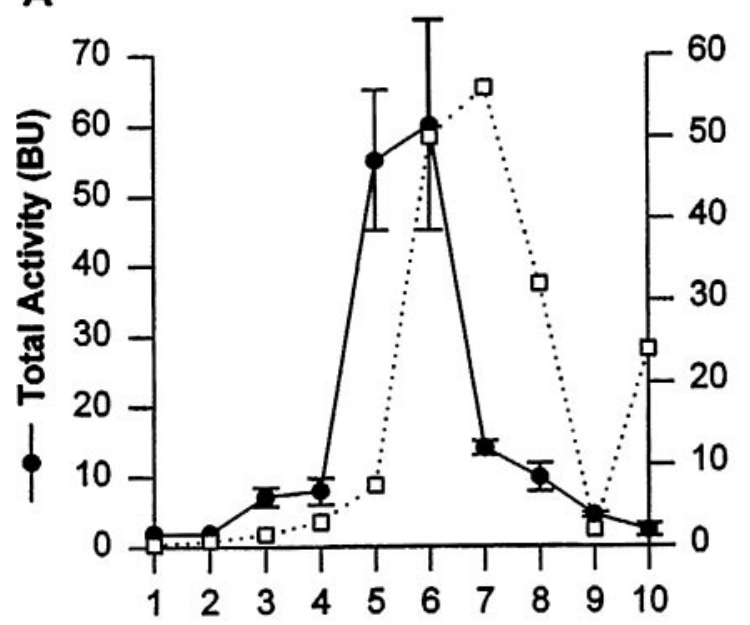

Fraction

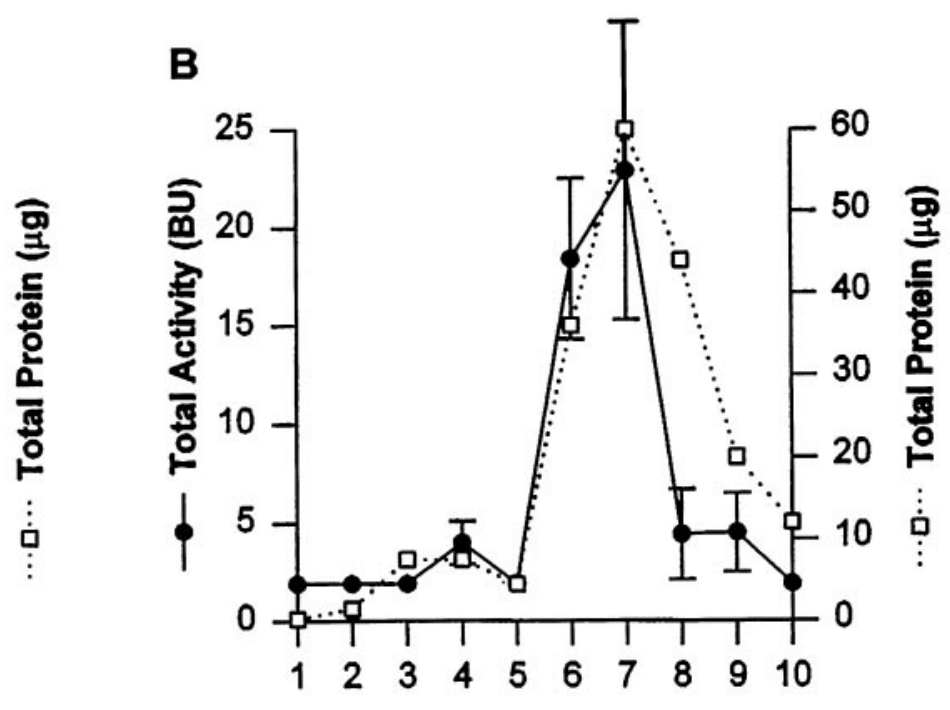

Fraction

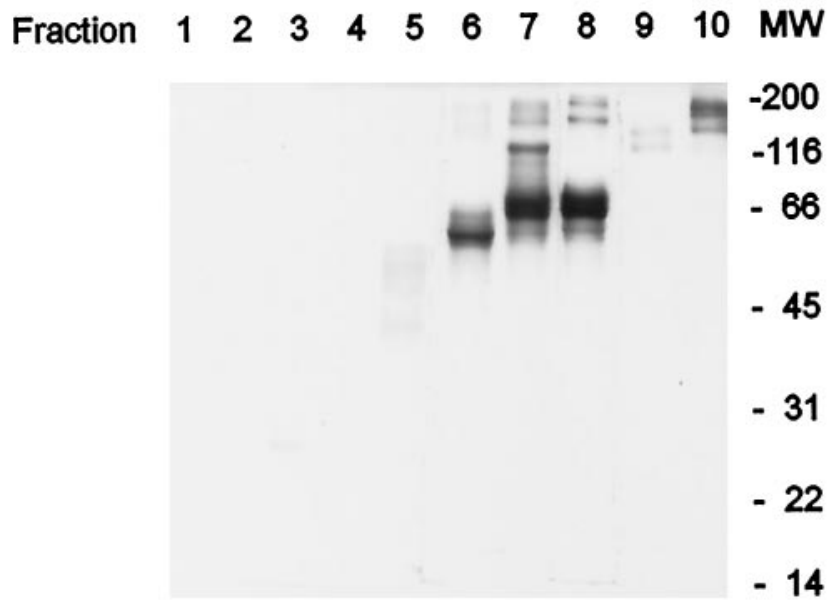

Fraction $\begin{array}{lllllllllllllllllll}1 & 2 & 3 & 4 & 5 & 6 & 7 & 8 & 9 & 10 & M W\end{array}$

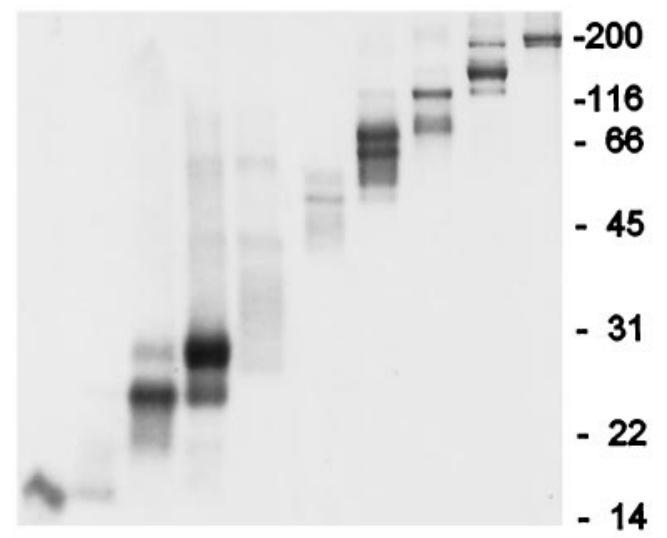

Figure 2. Estimation of the molecular weight $(M W)$ of the major survival-promoting activity in the active EDTA-citrate eluate from the first $\mathrm{Zn}{ }^{2+}$ affinity column. The eluate was divided and loaded onto two preparative SDS-PAGE gels, one run under nonreducing conditions and the other under reducing conditions (data not shown). Each gel was cut into 10 fractions, which were electroeluted, renatured, and bioassayed. Top panels plot total activity (BU $\pm \mathrm{SD}$, left ordinates, filled symbols connected by lines) and total protein (in micrograms, right ordinates, open symbols connected by dotted lines) for each fraction for nonreducing $(A)$ and reducing $(B)$ conditions. Bottom panels show analytical SDS-PAGE for each fraction indicated in the corresponding top panel, stained with fast Coomassie blue; the positions of broad-range $M W$ markers (Bio-Rad) are indicated at the right.

\section{Serum survival factor and selenoprotein-P have similar chemical properties}

SPPs purified from rat and human plasma exhibit multiple chemical similarities to the neuronal survival-promoting activity purified here from bovine serum, as well as to the serum survivalpromoting activity characterized by Kaufman and Barrett (1983), using different separation protocols. Both SPP and survivalpromoting activity are present in all tested sera (bovine, rat, human). Reported SPP MWs are 54-67 kDa (Eberle and Haas, 1993; Burk and Hill, 1994), compatible with the 50-60 kDa MW estimated for the active fraction from SDS-PAGE. Both rat and human SPPs and the serum biological activity have similar isoelectric points [5.44 for SPP, Herrman (1977); 5.5-5.8 for survival-promoting activity, Kaufman and Barrett (1983)]. SPP is histidine-rich (Burk and Hill, 1994), and amino acid composition performed on the $50-60 \mathrm{kDa}$ active protein (data not shown) indicated a high histidine content, which probably helps to account for the tight binding to $\mathrm{Zn}^{2+}$ affinity columns. Separate experiments (data not shown) indicated that $82 \%$ of the total activity from the active SDS-PAGE fraction bound to Concanavalin A, and activity also bound to heparin. These results and the observed binding of bioactivity to Cibacron blue 3-GA dye are consistent with the published properties of SPP (Yang et al., 1987; Eberle and Haas, 1993; Daher and Lente, 1994). Binding to Concanavalin A is consistent with the glycoprotein nature of SPP. Variable glycosylation might help to account for the diffuse na- 


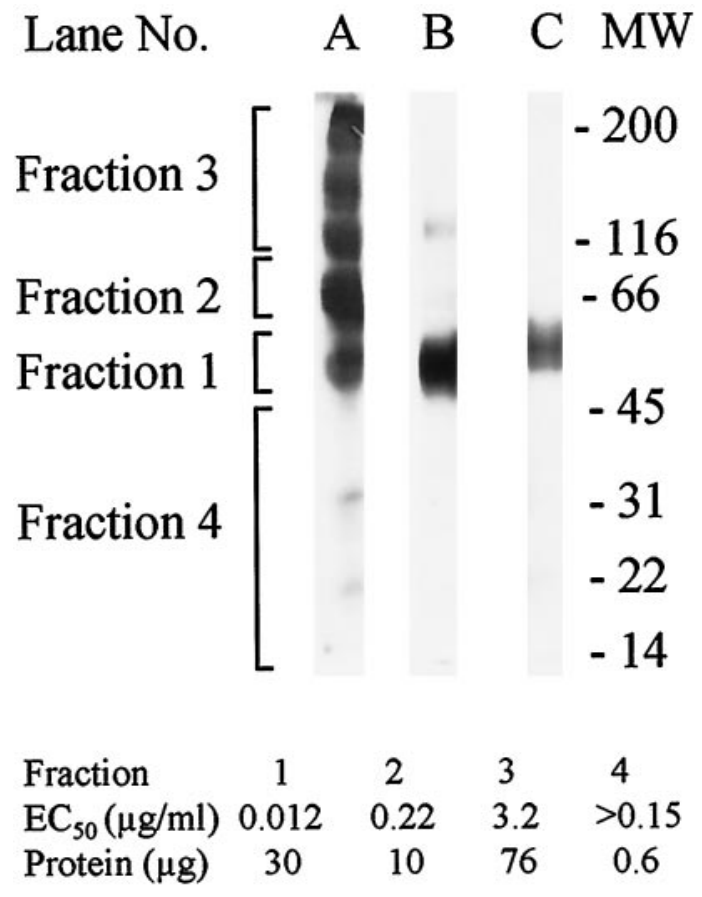

Figure 3. SDS-PAGE of active fractions from the ABx column. Lane A shows a gel strip from a preparative SDS-PAGE (nonreducing, fast Coomassie blue stain) of pooled, concentrated late $\mathrm{ABx}$ fractions. The remaining preparative gel was sectioned into four fractions, as indicated at the left. Proteins from each fraction were eluted and bioassayed. Lanes $B$ and $C$ show silver-stained analytical SDS-PAGE of the fraction with the highest specific activity (Fraction 1) run under nonreducing or reducing conditions, respectively. The numbers at the right indicate the position of prestained broad-range molecular weight $(M W)$ markers run under reducing conditions. The bottom table shows total protein and $\mathrm{EC}_{50}$ values for the fractions.

ture of the active protein bands on silver-stained nonreduced and reduced SDS-PAGE (see Fig. 3).

\section{Antibodies against a peptide within the bovine SPP sequence immunoprecipitate and inhibit neuronal survival-promoting activity}

To test further the hypothesis that part of the neuronal survivalpromoting activity of serum is attributable to SPP or an SPP-like protein, we generated antisera in rabbits against a synthetic 15-amino-acid peptide matching part of the bovine SPP sequence (see Materials and Methods). Antibodies were affinity-purified from these antisera by using the peptide antigen immobilized on agarose. Figure 5 shows silver stains of active fractions obtained from various stages in the purification protocol (Fig. 5A) and Western blots made by reacting the antibodies with these fractions (Fig. $5 B$ ). Note the progressive purification of a band at $\sim 55-60 \mathrm{kDa}$ that is recognized by the antibodies. (This band occurs at a MW slightly lower than the major BSA band in serum.) After purification with the Cibacron blue columns (Fig. 5, blue, lane 3), the antibodies also stained a band at $\sim 45 \mathrm{kDa}$. After cleavage with cyanogen bromide this band yielded an amino acid sequence identical to that in bovine SPP proteins, suggesting that this band is either a different form or a breakdown product of SPP-like protein(s). Indeed one form of SPP in rat serum has a MW of $45 \mathrm{kDa}$ (Himeno et al., 1996). The minor antibody staining at $\sim 30 \mathrm{kDa}$ might represent a fragment of SPP; this band became more prominent in fractions stored for longer times, and biological activity was recovered from this region in many exper-

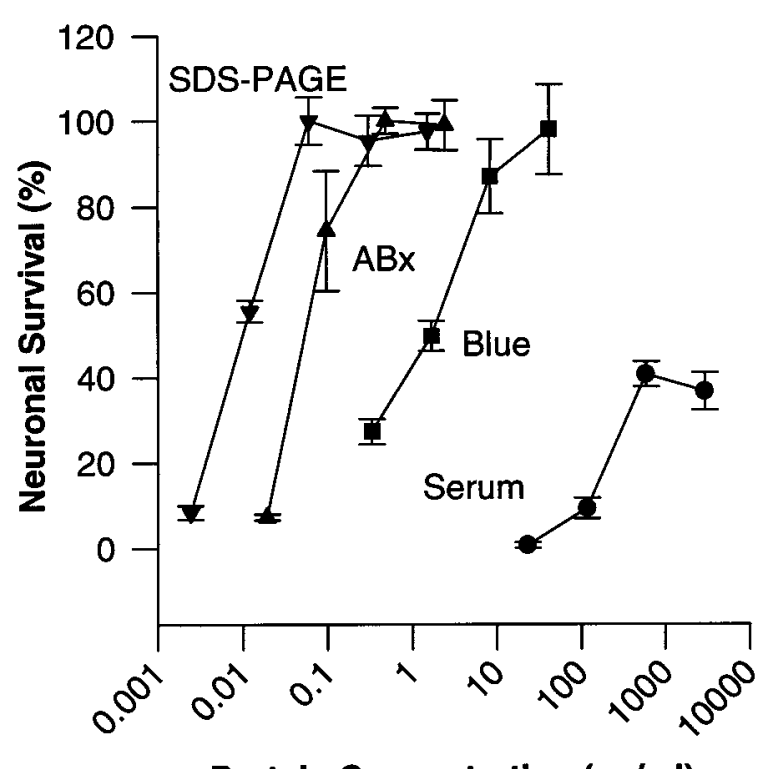

Figure 4. Neuronal survival as a function of protein concentration (log scale) at selected stages in the purification of neuronal survival-promoting activity from bovine serum. Filled circles show the results with the starting material, whole serum. Other symbols show the most active fractions after the indicated purification step (protocol in Table 1). Filled squares, Fraction eluted from the Cibacron blue 3-GA column between 0.5 and $3 \mathrm{~m}$ $\mathrm{NaCl}$; filled triangles, fraction eluted from $\mathrm{ABx}$ ion exchanger by $0.3-1 \mathrm{M}$ $\mathrm{NaCl}$; inverted filled triangles, protein recovered from final preparative SDS-PAGE in the range of 50-60 kDa. Neuronal survival is normalized to the maximal survival measured in the active fraction (EDTA-citrate eluate) from the first $\mathrm{Zn}^{2+}$ affinity column used in each purification protocol. Plotted values represent the mean \pm SEM of three culture wells from a representative experiment. The activity of the $\mathrm{ABx}$ fraction was very sensitive to oxidation and, in other experiments (see, for example, Fig. 1), had an even lower $\mathrm{EC}_{50}$ than that illustrated here.

iments (data not shown). Antibody-labeled bands at MWs $>100$ $\mathrm{kDa}$ may represent hetero- or homomeric associations involving SPP or the cross-reaction of antibodies with other proteins.

Affinity-purified antibodies against the 15-amino-acid SPP peptide were able to precipitate neuronal survival-promoting activity from the active ABx fraction (see Materials and Methods). Neuronal survival after precipitation with antibodies from two immunized rabbits was only $7.6 \pm 3.3 \%$ (SD) and $1.6 \pm 1.8 \%$, respectively (both $p<0.01$ ) of that measured in the $\mathrm{ABx}$ fraction alone, as compared with $91 \pm 29 \%$ after precipitation with nonspecific antibodies purified from preimmune serum (each value is the mean of seven culture wells from two independent experiments). Antibodies immobilized on Affigel 10 resin were able to purify the active molecule from the ABx fraction (data not shown). Binding to immobilized antibodies also enriched the neuronal survival-promoting activity of whole serum, but only by $\sim 50$-fold; the eluted material also contained contaminant proteins such as histidine-rich glycoprotein (data not shown). Some serum proteins (including SPP) bind tightly together in heteromeric complexes, and antibodies with higher affinity and/or greater specificity might be needed to purify SPP away from such complexes.

Figure 6 shows that antibodies against the SPP peptide also blocked most of the neuronal survival-promoting activity of the active $\mathrm{ABx}$ fraction. (The $\mathrm{ABx}$ fraction was used because it has a relatively high biological activity and was more stable than the active fraction renatured after SDS-PAGE.) Survival-promoting activity was not blocked by the immunizing peptide, by the 


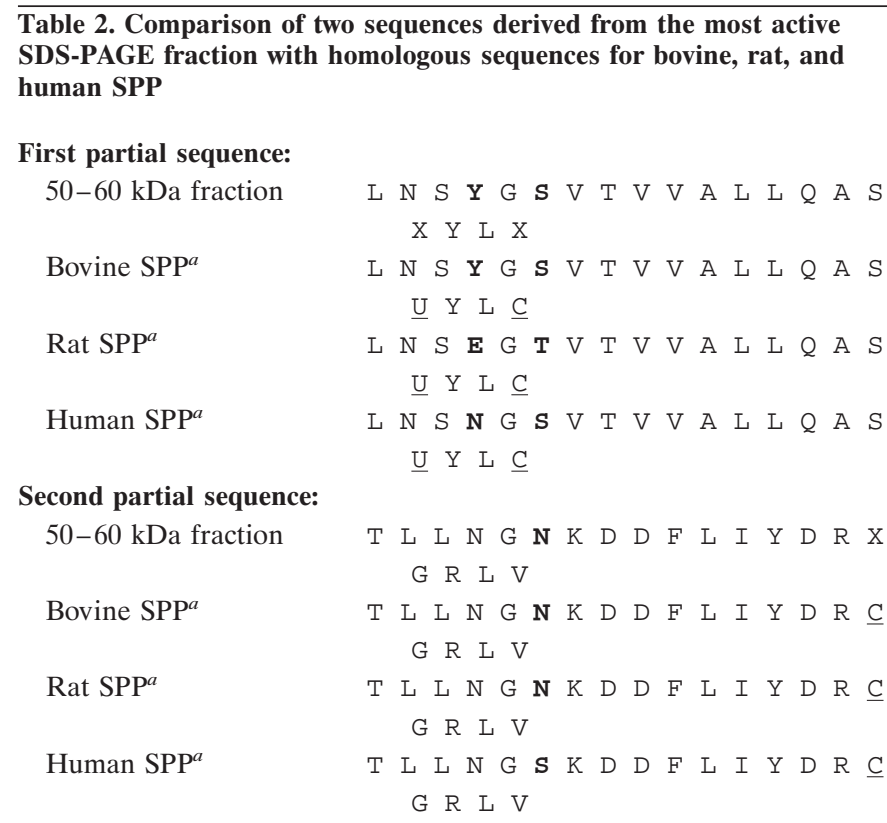

$\overline{\text { Bold letters indicate positions exhibiting interspecies variability. Underline indicates }}$ cysteine $(\mathrm{C})$ or selenocysteine $(\mathrm{U})$. X indicates undetermined amino acid.

${ }^{a}$ Protein sequences are cited from Saijoh et al. (1995).

combination of antibodies plus peptide, or by antibodies from preimmune serum. When tested alone, neither peptide nor antibodies increased neuronal survival. These results thus indicate that antibodies generated against an SPP fragment can bind to, and inhibit the activity of, the native form(s) of a serum survivalpromoting factor.

\section{Purified serum fraction promotes survival of neurons from different brain regions}

Table 3 shows the results of adding the active ABx fraction to neurons cultured from other embryonic brain regions (striatum, cerebral cortex, hippocampus, substantia nigra). The results demonstrate that the survival-promoting activity of this fraction is not restricted to septal neurons.

\section{Purified serum fraction promotes neuronal survival more effectively than inorganic selenium}

SPP and SPP-like proteins contain abundant selenium, 10 or 12 selenocysteines from a total of 362-383 amino acids. Because inorganic $\mathrm{Se}$ is a component of many defined media used for cell culture (Bottenstein and Sato, 1979), we tested the extent to which the neuronal survival-promoting effect of the SPP-like serum protein purified here could be mimicked by the addition of inorganic Se. Figure 7 plots the survival of septal neurons measured in different concentrations of the active $\mathrm{ABx}$ fraction and Na-selenite $\left(\mathrm{SeO}_{3}^{-2}\right)$. Both agents, tested alone or together, yielded the same maximal survival. Selenate $\left(\mathrm{SeO}_{4}^{2-}\right)$ also supported survival, but it was less effective than selenite on a molar basis (data not shown). Assuming that the active component of the $\mathrm{ABx}$ fraction was a $55 \mathrm{kDa} \mathrm{SPP}$-like protein, the $\mathrm{ABx}$ fraction was $\sim 66$ times more effective than Na-selenite on a molar basis $\left(\mathrm{EC}_{50} \sim 1.1 \mathrm{nM}\right.$ for $\mathrm{ABx}$ vs $\sim 73 \mathrm{nM}$ for selenite) and approximately six times more effective when corrected for Se content. The SDS-PAGE fraction containing more highly purified SPPlike protein would be expected to be $\sim 30$ times more effective than Na-selenite when corrected for Se content.

If some of the survival-promoting effects of the SPP-like pro-
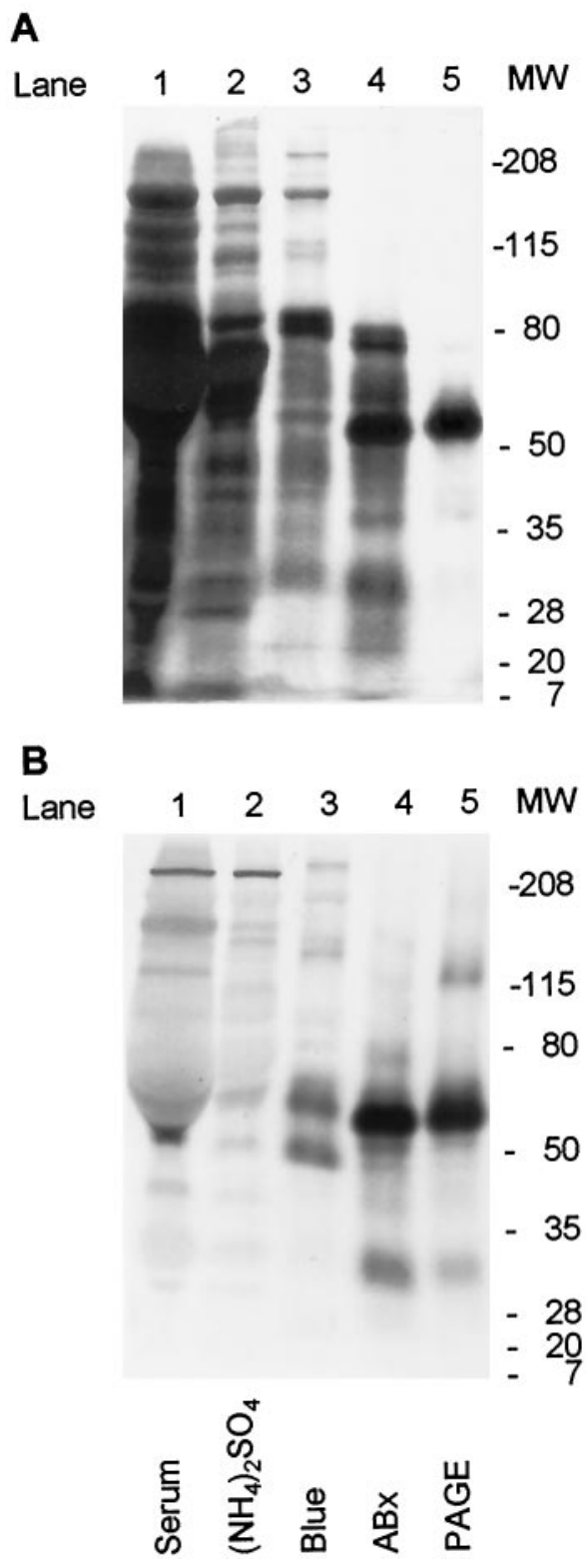

Figure 5. SDS-PAGE $(A)$ and Western blot $(B)$ of serum and four active fractions from the indicated steps of the purification protocol outlined in Table 1. Both gels were run under reducing conditions with aliquots of the same set of samples. The SDS-PAGE gel was silver-stained. The Western blot used affinity-purified antibodies from a rabbit immunized with a peptide synthesized from amino acids 244-259 in the deduced sequence of bovine SPP (HHRHKGPQRQGHSDN), stained as described in Materials and Methods. Molecular weight $(M W)$ standards are indicated at the right.

tein were attributable to its ability to deliver Se to cells, then denatured active fractions or partial or complete digests of active fractions also might have survival-promoting activity. Most of the activity was recovered after active fractions were boiled for 30 min, consistent with the heat stability reported by Kaufman and Barrett (1983). Activity also was recovered after a $24 \mathrm{hr}$ treatment with trypsin. Approximately $20 \%$ of the activity was recovered after $1 \mathrm{hr}$ in $6 \mathrm{M} \mathrm{HCl}$ at $160^{\circ} \mathrm{C}$ (this procedure, used to hydrolyze proteins completely to amino acids, also can reduce Se to selenide, $\mathrm{HSe}^{-}$). This result suggests that a small functional residue or residues of the SPP-like protein, including possibly inorganic 


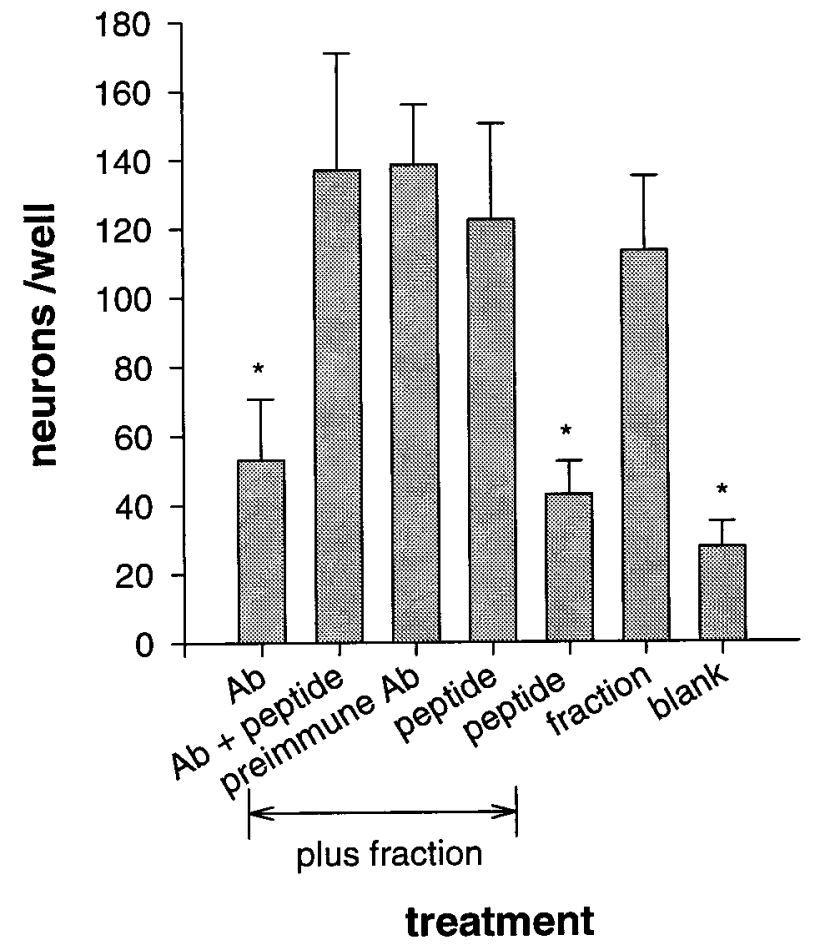

Figure 6. Inhibition of neuronal survival-promoting activity by affinitypurified antibodies against a 15 -amino-acid peptide in the deduced sequence of bovine SPP. The indicated substances were added to 3 DIV septal cultures; surviving neurons were counted at 6 DIV. The active fraction (late $\mathrm{ABx}, \mathrm{EC}_{50} \sim 60 \mathrm{ng} / \mathrm{ml}$ ) was present at $0.6 \mu \mathrm{g} / \mathrm{ml}$. The concentration of the antibodies $(A b)$ from immunized and preimmune rabbit sera was $1.5 \mu \mathrm{g} / \mathrm{ml}$, and that of the immunizing peptide (HHRHKGPQRQGHSDN) was $2 \mu \mathrm{g} / \mathrm{ml}$. Blank wells contained $2 \mu \mathrm{g} / \mathrm{ml}$ extra BSA. Values indicate the mean \pm SD from four culture wells from a single experiment; a replication of this experiment yielded similar results. ${ }^{*}$ Significant difference at $p<0.05$ from survival in ABx fraction alone.

Table 3. Active serum fraction supports survival of neurons from multiple brain regions

\begin{tabular}{lll} 
& \multicolumn{2}{l}{ Neurons/well (mean $\pm \mathrm{SD})$} \\
\cline { 2 - 3 } Brain region & Late ABx fraction & Control \\
\hline Cerebral cortex & $212 \pm 25^{* *}$ & $39 \pm 2$ \\
Hippocampus & $214 \pm 20^{* *}$ & $68 \pm 10$ \\
Substantia nigra & $168 \pm 30^{* *}$ & $31 \pm 6$ \\
Striatum & $223 \pm 29^{* *}$ & $12 \pm 3$
\end{tabular}

Cells from the indicated regions of E15 rat brain were cultured as described in Materials and Methods, with either the active ABx fraction $(0.3 \mu \mathrm{g} / \mathrm{ml})$ or $2 \mu \mathrm{g} / \mathrm{ml}$ extra BSA (control) added at 3 DIV. Viable neurons were counted at 6 DIV. Values represent the mean \pm SEM of four culture wells. ${ }^{* *}$ Indicates significant difference from control at $p<0.001$ (Bonferroni post-test comparing paired groups).

Se alone, can exert at least part of the activity of the intact molecule. These results also argue against the idea that the neuronal survival-promoting activity was attributable to a growth factor-like protein present as a minor component in the active fractions, because the known growth factor proteins would not be expected to retain any activity after acid hydrolysis.

\section{DISCUSSION}

\section{SPP (or SPP-like protein) in bovine serum supports} survival of cultured central neurons

This work demonstrates that a neuronal survival-promoting component in bovine serum can be purified $>40,000$-fold by using a

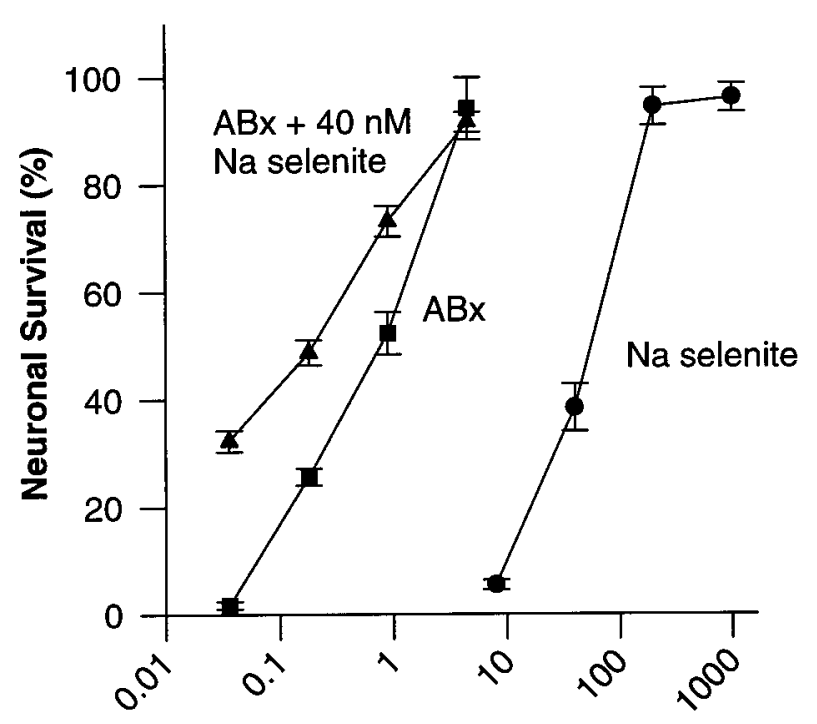

\section{Protein or Na Selenite Concentration (nM)}

Figure 7. Concentration dependence of the neuronal survival-promoting activity of the $\mathrm{ABx}$ active fraction (filled squares), Na-selenite (filled circles), and the combination of the $\mathrm{ABx}$ active fraction plus $40 \mathrm{nM}$ Na-selenite (filled triangles). Survival is normalized as in Figure 2. The $\log$ scale on the abscissa indicates the molar concentration of protein in the $\mathrm{ABx}$ active fraction or the molar concentration of Se in Na-selenite. Values represent the mean \pm SEM of four culture wells from two independent experiments.

combination of ammonium sulfate precipitation, $\mathrm{Zn}^{2+}$ affinity and Cibacron blue 3-GA affinity chromatography, ABx ion exchange, and preparative SDS-PAGE (see Table 1). The most purified active fraction had an $\mathrm{EC}_{50}$ of $12 \mathrm{ng} / \mathrm{ml}$ and yielded what appeared to be a single band at $\sim 55 \mathrm{kDa}$ on silver-stained SDS-PAGE under reducing conditions (see Fig. 3). A sequence analysis of peptides from this final fraction matched those from cDNAs of bovine SPP. Further evidence that SPP (or an SPP-like protein) has significant survival-promoting activity is that affinity-purified antibodies against a peptide from bovine SPP sequence were able to inhibit and immunoprecipitate the survival-promoting activity in a partially purified serum fraction (see Fig. 6). The survival-promoting activity extended to many types of central neurons (see Table 3 ).

At least $1 \mathrm{mg}$ of protein could be recovered in the active $\mathrm{ABx}$ fraction from a purification run starting with 11 of bovine serum, suggesting that the serum concentration of SPP is at least $20 \mathrm{nM}$. Taking into account the loss during purification, this estimate is consistent with the concentrations of SPP reported for rat and human serum (500 and $50 \mathrm{~nm}$, respectively) (Burk and Hill, 1994).

\section{Selenium and selenoproteins}

Selenium is a trace element that is necessary for normal body function (for review, see Burk, 1983; Arthur and Beckett, 1994). Se absorbed by the intestines is incorporated into SPP by the liver. SPP is secreted into the blood; the serum SPP level increases within $4 \mathrm{hr}$ after Se intake (Burk et al., 1991). Se in selenoproteins is in the form of selenocysteine, which is synthesized cotranslationally from serine and selenide and is inserted by seryl-tRNA at positions that are specified by certain UGA codons in mRNA. These codons are decoded as selenocysteine rather than as a stop codon under the influence of a secondary structural 
selenocysteine insertion sequence element in the $3^{\prime}$ untranslated region of selenoprotein mRNAs (Sunde, 1990; Stadtman, 1991).

Identified selenoproteins other than SPP include multiple forms of glutathione peroxidase (cytosolic, plasma, phospholipid hydroperoxide, gastrointestinal, viral), type I iodothyronine 5-deiodinase, sperm capsule selenoprotein, and selenoprotein-W in muscle (for review, see Sunde, 1990; Arthur and Beckett, 1994; Shisler et al., 1998). The major form of bovine SPP-like protein encodes a mature protein of 383 amino acids, including 12 selenocysteines and 15 cysteines [deduced from the cDNA sequence in Saijoh et al. (1995)]. Like rat and human SPP, it has a 19amino-acid signal peptide at its $\mathrm{N}$-terminal that is typical for secreted proteins. One form of bovine SPP-like cDNA contains a tandem repeat of seven CATCCCs, translated as seven histidineproline repeats. Excluding the tandem repeat, the nucleotide sequence of bovine SPP-like protein is 77 and $82 \%$ homologous to that of rat and human SPP, respectively. To our knowledge the present study is the first purification of bovine SPP. Purification of rat and human SPPs currently requires biochemical separation procedures combined with immunoaffinity chromatography. Neither SPP nor SPP-like proteins have yet been expressed successfully in transfected cells.

\section{Possible mechanism(s) underlying the neuronal survival-promoting activity of SPP}

Little is known concerning the functions of SPP, but studies of other neuronal survival-promoting factors and other selenoproteins suggest at least three possible ways by which SPP might enhance the survival of cultured central neurons: as a source of $\mathrm{Se}$, as a neurotrophic factor, and/or as an antioxidant.

SPP might act as a carrier/sequesterer, transporting Se to neurons (and/or non-neuronal cells) in a biologically safe and available form for use in synthesizing survival-enhancing Secontaining proteins within the CNS. Consistent with this hypothesis, SPP contains a major part of Se in plasma ( $\sim 60$ and $40 \%$ of total plasma Se in rat and human, respectively), and inorganic Se (selenite) itself increases neuronal survival (see Fig. 7) (Bottenstein and Sato, 1979). The brain can take up SPP and, in fact, shows priority over other tissues in taking up SPP in Se-deficient animals (Burk, 1983). However, SPP probably must be degraded for its covalently bound Se to become biologically available, and thus SPP differs from carriers like transferrin, which can be reused many times for ligand transport.

The SPP-like protein purified from serum supported neuronal survival more effectively than selenite on a molar or per Se basis (see Fig. 7). Purified fractions might have had a higher specific activity than selenite if the Se in SPP were less toxic or more readily used by cells than inorganic Se. Also, binding to BSA (Deagen et al., 1993) might decrease the free selenite concentration in the medium. Bottenstein and Sato (1979) reported that neuronal survival decreased for selenite concentrations exceeding $30 \mathrm{~nm}$ in their N2 medium, which contained no BSA, whereas in our culture medium containing BSA, selenite concentrations of up to $10 \mu \mathrm{M}$ did not diminish neuronal survival.

Alternatively or in addition, SPP might act like a conventional neurotrophic factor (e.g., basic fibroblast growth factor) (Walicke, 1988; Eckenstein, 1994), binding to membrane receptors and activating second messenger cascades that enhance neuronal survival. SPP is expressed in brain (Saijoh et al., 1995), although its precise cellular locations and the factors controlling its synthesis and release within the brain are not yet known. It is thus possible that some of the survival-promoting activity of inorganic Se was attributable to enabling/promoting the synthesis of SPP within the cultures. The $\mathrm{EC}_{50}$ of the most active SDS-PAGE fraction was $12 \mathrm{ng} / \mathrm{ml}$, suggesting a $K_{\mathrm{D}}$ of $\sim 200 \mathrm{pM}$, a value within the range of $K_{\mathrm{D}}$ values for many neurotrophic factors. The actual $K_{\mathrm{D}}$ for SPP might be even lower if SPP renaturation after SDS-PAGE were incomplete.

SPP also might act like, e.g., catalase (Walicke et al., 1986), enhancing neuronal survival by defending neurons against oxidative damage. Selenocysteine is active in transferring electrons, and other selenoproteins function as redox enzymes. For example, glutathione peroxidase degrades $\mathrm{H}_{2} \mathrm{O}_{2}$ to $\mathrm{H}_{2} \mathrm{O}$ at the expense of the reduced form of glutathione and NADH. Although SPP lacks glutathione peroxidase activity (Yang et al., 1987), SPP and/or SPP-like protein might participate in other aspects of antioxidant defense. Hill and Burk (1997) present evidence that SPP contributed to the protection against lipid peroxidation that was measured after the administration of Se to Se-deficient rats.

Transition metals such as $\mathrm{Fe}^{3+}$ can induce oxidative stress in cell culture by accelerating the conversion of $\mathrm{H}_{2} \mathrm{O}_{2}$ into the more damaging hydroxyl free radicals (Halliwell and Gutteridge, 1990). Many metal chelators ameliorate the cell death caused by oxidative stress (Beckman et al., 1990; Troy et al., 1996). SPP and/or SPP-like protein might serve as a metal chelator on the basis of its high histidine content and tight binding to $\mathrm{Zn}^{2+}$ affinity columns.

In summary, we purified from serum a neuronal survivalpromoting activity and have presented evidence that this activity is mediated by SPP. Further work will be needed to determine whether SPP promotes neuronal survival simply by supplying cells with Se, or whether SPP also has additional, more direct neurotrophic or neuroprotective functions.

\section{REFERENCES}

Aizenman Y, de Vellis J (1987) Brain neurons develop in a serum and glial free environment: effects of transferrin, insulin, insulin-like growth factor-I, and thyroid hormone on neuronal survival, growth, and differentiation. Brain Res 406:32-42.

Arthur JR, Beckett GJ (1994) New metabolic roles for selenium. Proc Nutr Soc 53:615-624.

Beckman JS, Beckman TW, Chen J, Marshall PA, Freeman BA (1990) Apparent hydroxyl radical production by peroxynitrite: implication for endothelial injury from nitric oxide and peroxide. Proc Natl Acad Sci USA 87:1620-1624.

Bottenstein J, Sato GH (1979) Growth of a rat neuroblastoma cell line in serum-free supplemented medium. Proc Natl Acad Sci USA 76:514-517.

Burk RF (1983) Biological activity of selenium. Annu Rev Nutr 3:53-70.

Burk RF, Hill KE (1994) Selenoprotein-P, a selenium-rich extracellular glycoprotein. J Nutr 124:1891-1897.

Burk RF, Hill KE, Read R, Bellew T (1991) Response of rat selenoprotein-P to selenium administration and fate of its selenium. Am J Physiol 261:E26-E30.

Daher R, Lente FV (1994) Concanavalin A-bound selenoprotein in human serum analyzed by graphite furnace atomic absorption spectrometry. Clin Chem 40:62-70.

Deagen JT, Butler JA, Zachara BA, Whanger PD (1993) Determination of the distribution of selenium between glutathione peroxidase, selenoprotein-P, and albumin in plasma. Anal Biochem 208:176-181.

Eberle B, Haas HJ (1993) Purification of selenoprotein-Ph from human serum. J Trace Elem Electrolytes Health Dis 7:217-221.

Eckenstein FP (1994) Fibroblast growth factors in the nervous system. J Neurobiol 25:1467-1480.

Ferrari G, Yan CYI, Greene LA (1995) $N$-acetylcysteine (D- and L-stereoisomers) prevents apoptotic death of neuronal cells. J Neurosci 15:2857-2866.

García Jr JE, Nonner D, Ross D, Barrett JN (1992) Neurotoxic components in normal serum. Exp Neurol 118:309-316.

Halliwell B, Gutteridge JM (1990) Role of free radicals and catalytic metal ions in human disease: an overview. Methods Enzymol 186:1-85. 
Herrman JL (1977) The properties of a rat serum protein labeled by the injection of sodium selenite. Biochim Biophys Acta 500:61-70.

Hill KE, Burk RF (1997) Selenoprotein-P: recent studies in rats and in humans. Biomed Environ Sci 10:198-208.

Himeno S, Chittum HS, Burk RF (1996) Isoforms of selenoprotein-P in rat plasma. J Biol Chem 271:15769-15775.

Howard MK, Burke LC, Mailhos C, Pizzey A, Gilbert CS, Lawson WD, Collins MKL, Thomas NSB, Latchman DS (1993) Cell cycle arrest of proliferating neuronal cells by serum deprivation can result in either apoptosis or differentiation. J Neurochem 60:1783-1791.

Kaufman LM, Barrett JN (1983) Serum factor supporting long-term survival of rat central neurons in culture. Science 220:1394-1396.

Kawamoto J, Barrett JN (1986) Cryopreservation of primary neurons for tissue culture. Brain Res 384:84-93.

Koide T, Foster D, Yoshitake S, Davie EW (1986) Amino acid sequence of human histidine-rich glycoprotein derived from the nucleotide sequence of its cDNA. Biochemistry 25:2220-2225.

Lee MK, Tuttle JB, Rebhun LI, Cleveland DW, Frankfurter A (1990) The expression and posttranslational modification of a neuron-specific $\beta$-tubulin isotype during chick embryogenesis. Cell Motil Cytoskeleton 17:118-132.

Manelli AM, Cadman ED, Shiosaki K, Puttfarcken PS (1997) The presence of the complement cascade does not lead to neuronal cell death in primary hippocampal cultures. Brain Res Bull 42:187-193.

Messer A, Maskin P, Mazurkiewicz JE (1980) Effects of using a chemically defined medium for primary rat monolayer cerebellar cultures: morphology, GABA uptake, and kainic acid sensitivity. Brain Res 184:243-247.

Miller TM, Johnson Jr EM (1996) Metabolic and genetic analyses of apoptosis in potassium/serum-deprived rat cerebellar granule cells. J Neurosci 16:7487-7495.

Moos Jr M, Nguyen NY, Liu TY (1988) Reproducible high yield sequencing of proteins electrophoretically separated and transferred to an inert support. J Biol Chem 263:6005-6008.

Nonner D, Barrett EF, Barrett JN (1996) Neurotrophin effects on survival and expression of cholinergic properties in cultured rat septal neurons under normal and stress conditions. J Neurosci 16:6665-6675.

Rechler MM, Nissley SP (1986) Insulin-like growth factor (IGF)/somatomedin receptor subtypes: structure, function, and relationships to insulin receptors and IGF carrier proteins. Horm Res 24:152-159.

Saijoh K, Saito N, Lee MJ, Fujii M, Kobayashi T, Sumino K (1995) Molecular cloning of cDNA encoding a bovine selenoprotein-P-like protein containing 12 selenocysteines and a (His-Pro) rich domain insertion, and its regional expression. Mol Brain Res 30:301-311.

Shisler JL, Senkevich TG, Berry MJ, Moss B (1998) Ultraviolet-induced cell death blocked by a selenoprotein from a human dermatotropic poxvirus. Science 279:102-105.

Skaper SD, Adler R, Varon SS (1979) A procedure for purifying neuronlike cells in culture from central nervous tissue with a defined medium. Dev Neurosci 2:233-237.

Stadtman TC (1991) Biosynthesis and function of selenocysteinecontaining enzymes. J Biol Chem 266:16257-16260.

Sunde RA (1990) Molecular biology of selenoproteins. Annu Rev Nutr $10: 451-474$.

Takeshima T, Johnson JM, Commissiong JW (1994) Mesencephalic type 1 astrocytes rescue dopaminergic neurons from death induced by serum deprivation. J Neurosci 14:4769-4779.

Troy CM, Derossi D, Prochiantz A, Greene LA, Shelanski ML (1996) Downregulation of $\mathrm{Cu} / \mathrm{Zn}$ superoxide dismutase leads to cell death via the nitric oxide-peroxynitrite pathway. J Neurosci 16:253-261.

Walicke PA (1988) Basic and acidic fibroblast growth factors have trophic effects on neurons from multiple CNS regions. J Neurosci $8: 2618-2627$.

Walicke P, Varon S, Manthrope M (1986) Purification of a human red blood cell protein supporting the survival of cultured CNS neurons, and its identification as catalase. J Neurosci 6:1114-1121.

Yan J (1996) Purification and identification of selenoprotein-P-like protein from bovine serum as a survival-promoting factor for cultured neurons. PhD thesis, University of Michigan.

Yan J, Barrett JN (1994) A new neutral pH multiphasic buffer system for SDS-polyacrylamide gel electrophoresis of protein. Protein Sci 3[Suppl 1]:97.

Yan J, Barrett JN (1996) Purification of a survival-promoting factor for cultured neurons from bovine serum, and its identification as a selenoprotein-P-like protein. Soc Neurosci Abstr 22:745.

Yang JG, Morrison-Plummer J, Burk RF (1987) Purification and quantitation of a rat plasma selenoprotein distinct from glutathione peroxidase using monoclonal antibodies. J Biol Chem 262:13372-13375.

Yavin Z, Yavin E (1980) Survival and maturation of cerebral neurons on poly-L-lysine surfaces in the absence of serum. Dev Biol 75:454-459.

Yip TT, Nakagawa Y, Porath J (1989) Evaluation of the interaction of peptides with $\mathrm{Cu}(\mathrm{II}), \mathrm{Ni}(\mathrm{II})$, and $\mathrm{Zn}(\mathrm{II})$ by high-performance immobilized metal ion affinity chromatography. Anal Biochem 183:159-171. 